\title{
Processing of Sweet Corn
}

\author{
Mariusz Szymanek \\ University of Life Sciences in Lublin \\ Poland
}

\section{Introduction}

\subsection{Sweet corn kernel structure, chemical composition, and sensory qualities}

Sweet corn cobs constituting raw material for processing must be characterized by the highest quality of kernels. Kernel quality is defined not just by the chemical and sensory properties, but also by the mechanical parameters of kernels. This appears to fully justify joint consideration of all those properties. Sweet corn is probably a mutant of fodder corn (Orłowski, 2000). Significant differences between the two are related more to the genetics than to the structure of the kernels. As emphasized by Salunkhe and Kadam (1998), the structure of the kernels is strongly related to thegenetic modification and to ripeness.

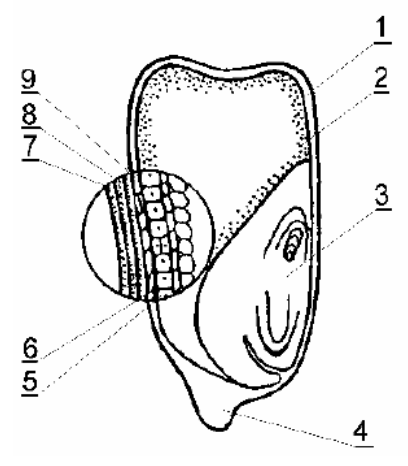

Fig. 1. Schematic of longitudinal cross section of a sweet corn kernel: 1 - pericarp, 2 endosperm, 3 - germ, 4 - pedicel, 5 - aleurone layer, 6 - tube cells, 7 - epicarp, 8 - mesocarp, 9 - cross cells (Salunkhe and Kadam, 1998).

Sweet corn kernel is built of the pedicel, the pericarp, the germ, and the parenchyma (Fig. 1). The pedicel is a hard and fibrous remnant of the tissue that joins the kernel to the cob core (Szpaar and Dregiew, 1999). During kernel shearing, a part of the pedicel remains on the kernel, which has a negative effect on its nutritional value. Kernel shape is described as flattened and wedge-like, with the tip much broader than the base end by which the kernel is attached to the cob core. The kernel is deep set on an abbreviated shoot (rachis) forming the cob, and is covered with a thin pericarp. The pericarp is a component of the seed coat 
tissue and forms the outer layer of the kernel. The thickness of the layer determines the kernel skin level of tenderness. This feature is important in the estimation of kernel quality for processing. As compared to other varieties, sweet corn is characterized by lower thickness of the epicarp, on average 25-30 $\mu \mathrm{m}$ (Ito and Brewbaker, 1991). The epicarp is composed of a single layer of pericarp, in the cavities of which single cells of the mesocarp are located. It also includes one or two layers of cross-cells and one or more tube cells adherent to the pericarp. The germ, located obliquely at the base of the kernel, is large and constitutes about $15 \%$ of the volume or $11.5-14 \%$ of the weight of the kernel. Germ size, however, is cultivar-related and may constitute $5 \%$ of the mass of the whole kernel (Puangnak, 1998). In turn, the parenchyma is the largest element of the kernel. It is in the parenchyma that the sugars, starch, and water-soluble polysaccharides are accumulated in. In the phase of consumption ripeness, the consistency of kernels is soft, delicate, creamy, and the taste is sweet and fragrant (Reyes and Varseveld, 1982). The kernel seed coat has colours from pale yellow to orange, often also with a violet tint and shiny. In the genotype of sweet corn, apart from the genotype of sweet corn, except gene su (sugary) gene determining the sweet taste and tenderness of the kernel, also other genes have been discovered, responsible for enhancing the sweetness and the taste and utility qualities - the gene se (sugary enhancement) and the gene sh2 (shrunken 2). Genetic combinations of the genotypes su and sh2 helped in the creation of very sweet cultivars (Simonne et al., 1999). In the phase of full ripeness, sweet corn has wrinkled kernels, almost completely filled with vitreous parenchyma, mostly white or yellow in colour. The reserve substance of the parenchyma is composed of amylodexstrins which are responsible for the sweet taste. The kernel has a bulbous shape, oval, wedge-shaped or angular, a smooth or wrinkled surface, and white, yellow, read or brownish colouring. It is enclosed in a cover formed from fused pericarp and seed coat, beneath which there is a layer of aleurone cells, the parenchyma, and the germ. From the moment of pollination till harvest the cob of sweet corn undergoes numerous physical and chemical transformations which largely affect the taste and the quality of kernels. The taste is especially strongly affected by the transformations of sugars (Wong, 1994). With respect to the content of sugars, three types of sweet corn cultivars are distinguished: normally sweet cultivars, type su (sugary), with sugar content of 4-6\%, cultivars with increased sugar content, type se (sugary enhancement) $-6-8 \%$, and very sweet cultivars, type sh2 (shrunken 2) - 8-12\% (Warzecha, 2003). Apart from the content of sugars, fresh mass of sweet corn kernels contains $2.1-4.5 \%$ of proteins, $3-20 \%$ of starch, $1.1-2.7 \%$ of fats, $0.9-1.9 \%$ of cellulose, $9-12 \mathrm{mg}$ of vitamin C, small amounts of vitamins A, B1, B2, PP, and mineral components such as: sodium, potassium, magnesium, calcium, phosphorus, iron, selenium, copper, nickel and chromium (Felczyński et. al., 1999; Lee and McCoon, 1981). The chemical composition of the kernels is related to the weather conditions, ripeness, and method of storage (Salunkhe and Kadam, 1998). According to data from the USDA (Hardenburg and Watada, 1986), the nutritional value of sweet corn kernels is related to the content of water $(72.7 \%)$ and to the total content of solid parts $(27.3 \%)$. Solid parts include hydrocarbons $(81 \%)$, proteins $(13 \%)$, lipids $(3.5 \%)$, and others $(2.5 \%)$. Starch is the dominant hydrocarbon component. Sweet corn has the highest nutritional value in the phase of milk ripeness. With progressing phase of ripeness, in the transition to the phase of wax ripeness the content of sugars decreases, accompanied by an increase in the content of starch (Suk and Sang, 1999). In $100 \mathrm{~g}$ of kernels there is about $3.03 \mathrm{~g}$ of saccharine, $0.34 \mathrm{~g}$ of glucose and 
$0.31 \mathrm{~g}$ of fructose. The content of saccharine increases, and that of reducing sugars decreases as the kernels reach the optimum ripeness. The content of proteins in the kernels decreases from the surface towards the centre of the kernel. The content of proteins, free aminoacids, water-soluble and insoluble hydrocarbons, increases up to the phase of wax ripeness, and then gradually decreases (Azanza et. al., 1996). The amounts of the particular components in various cultivars and in various phases of ripeness variable. In comparison to other cereals, sweet corn is relatively rich in oil. Approximately $90 \%$ of the oil is accumulated in the germ. Sweet corn is more tasty than other corn species, thanks to its high content of water-soluble polysaccharides. That component imparts to the kernels their tender and creamy character. The most important parameters that affect the sensory quality of the kernels include sweetness, texture, and taste (Wong and Swiader, 1995). Sweetness depends on the content of sugars, while texture depends on a number of factors, such as tenderness of the seed coat, moisture, content of water-soluble polysaccharides. Taste, in turn, is frequently associated with the content of DMS (dimethyl sulphide). Decrease in kernel quality related to loss of taste and aroma after the harvest is a problem for the processing industry. The loss of taste in fresh or frozen state of the kernels is caused by enzyme activity (Collins and Biles, 1996). Fresh kernels are characterized by faint aroma or its total absence. Wade (1981) states that cut kernels have three characteristic types of aroma. Two of these are similar to the aroma of fresh green vegetables, and the third is described by that author as a methol-type aroma. With progressing ripeness of sweet corn, the level of DMS in the kernels decreases, which is a serious problem for the processing industry due to the related considerable loss of taste of processed sweet corn products.

The consumption quality of fresh sweet corn largely depends on the content of sugars and water-soluble hydrocarbons in the kernels (Evensen and Boyer, 1986). The quality of sweet corn kernels can be determined in many ways. The basic discriminant of kernels for the processing industry is kernel hardness and taste. One of the most important factors determining the quality of kernels for processing is the use of cultivars characterized by uniform ripening. The choice of cultivar affects not only the yield of kernels cut off cobs, but also the taste quality of the kernels. Other quality factors include the colour, sweetness, and tenderness of the kernel cover. With ripening, the cover becomes harder and harder. The quality of sweet corn is correlated to the content of sugars. The transformation of sugars into starch is also related to decreasing moisture content of the kernels.

\subsection{Characterization of sweet corn varieties}

The choice of variety is one of the more important factors the determine whether sweet corn production is a success. Population (fixed) varieties have been largely replaced in cultivation by hybrid (heterotic) varieties, created by man in the first half of the 20th century as new forms of the crop plant. Hybrid varieties spread less, produce bigger and evenly ripening cobs, and are higher yielding compared to the population varieties. They are characterized by high sensory qualities and are suitable for direct consumption and for the processing industry alike. They meet the requirements of the fruit and vegetable processing industry in terms of having very delicate kernel skin and kernels easy to separate from the cobs in whose mass the kernels constitute $30-40 \%$. Primary differences among the hybrid varieties include the duration of their vegetation period, content of sugars, and suitability for various 
uses. The productive value of the varieties is determined primarily by their yield capacity and the earliness of their ripening.

Producers involved in sweet corn growing for direct consumption are interested in obtaining a large number of well kernelled cobs. Those producing sweet corn for industrial processing expect a high yield of material suitable for processing. In terms of the length of the vegetation period the following groups of corn varieties are distinguished:

- $\quad$ early varieties (70-80 days),

- medium early varieties (85-90 days),

- $\quad$ late varieties (95-110 days).

Also important is the division of varieties with respect to the content of sugars in kernels at the phase of harvest ripeness. With reference to their genetic features, they are classified as:

- $\quad$ normally sweet, with the gene "su-1" (sugary),

- with increased content of sugars, with the gene "se" or "se+" (sugary enhanced),

- $\quad$ very sweet, with the gene "sh-2"(shrunken 2).

Variety selection is an important consideration in sweet corn production and includes factors such as sweetness, days to maturity, seed color, size, yield potential, and tolerance to pests. The Cooperative Extension Service can provide a list of varieties recommended for each region.

\begin{tabular}{|c|c|c|c|}
\hline Genotype & Sweetness & $\begin{array}{c}\text { Conversion of } \\
\text { sugars to starch }\end{array}$ & Isolate form \\
\hline Normal sugary (su) & Moderately sweet & Rapid & (sh2) vaieties \\
\hline $\begin{array}{c}\text { Sugary enhanced } \\
(\text { se), }(\mathrm{se}+)\end{array}$ & $\begin{array}{c}\text { Sweeter than }(\mathrm{su}) \\
\text { less sweet than } \\
(\mathrm{sh} 2)\end{array}$ & Not as rapid as (su) & (sh2) vaieties \\
\hline $\begin{array}{c}\text { Super sweet or } \\
\text { shrunken }(\mathrm{sh} 2)\end{array}$ & Very sweet & Very slow & $\begin{array}{c}(\mathrm{su}),(\mathrm{se}),(\mathrm{sh}+) \\
\text { vaieties }\end{array}$ \\
\hline
\end{tabular}

Table 1. Sweet Corn Genotypes (http:/ / attra.ncat.org/attra-pub/PDF/ sweetcorn.pdf)

Modern sweet corn varieties are classified as: "normal sugary" (su); "sugary enhanced" (se) and (se+); and "shrunken" (sh2), also called "super sweet." These differ in flavor and tenderness, and in the rate at which starches are converted to sugar. In general, (se) lines yield the best, followed by (sh2), and finally (su). Cross-pollination of sweet corn with other kinds of corn or with some other sweet corn genotypes can result in starchy-tasting kernels. Generally, a minimal isolation distance of 250 feet between those varieties or types is recommended; 700 feet, however, is preferred for more complete isolation. Table 1 summarizes the general characteristics of sweet corn genotypes, including isolation requirements. The normally sweet varieties contain $4-6 \%$ of sugars in fresh kernel mass, those with higher sugar content from 6 to $8 \%$, and the very sweet varieties, sometimes also called super sweet or extra sweet, from 8 to $12 \%$. Another criterion of division or classification of cucltivars is the colour of their kernels which can be yellow (the largest group of varieties), white, yellow-white (bicolor) and red (Wong, 1994). 


\section{Uses of sweet corn}

Sweet corn kernels can be consumed both as fresh produce and in processed forms. In practice, most frequently three basic directions of their utilization are distinguished:

- $\quad$ direct consumption - cobs harvested at milk ripeness of seed, for so-called freshproduce market;

- $\quad$ fruit-and-vegetable processing industry - cobs harvested at late-milt ripens of seed, for pickles and frozen foods;

- $\quad$ industrial processing - cobs harvested at full ripeness of seed, for flour, meal, etc.

\section{Sweet corn processing technology}

\subsection{Harvest of sweet corn cobs}

Sweet corn for processing is harvested at a relatively immature stage as compared to field corn. Processing of corn is used to increase its shelf life but as a consequence, a significant loss of nutrients may occur via heat degradation or leaching (Scott and Eldridge, 2005). Sweet corn for processing is picked at different stages of maturity depending on the way it is to be processed. The corn for freezing is harvested at about the same stage as that for fresh market, while the corn for whole kernel pack and cream-style is harvested at a slightly later stage of maturity. For whole kernel canning and freezing, optimum kernel moisture ranges from 70 to $76 \%$. For cream-style canning corn, optimum kernel moisture is about $66 \%$. Experience showed that it correlated very closely with the moisture percentage and with postharvest grade evaluation Olson (2000). There are many reasons why crops should be harvested at optimal maturity for their specific end uses. An accurate determination of the sweet corn maturity for harvest can ensure the best possible crop yield and quality. The optimum moisture for harvesting shrunken sweet corn for freezing and canning is no less than $76 \%$ and no more than $79 \%$. This compares to the range for standard sweet corn of $70-72 \%$. Because the shrunken sweet corn loses only about $1 / 4$ percent of moisture per 24 -hr period at the $76 \%$ level as compared to $1 \%$ per $24-\mathrm{hr}$ period for standard sweet corn, the harvest window for shrunken corn harvest for a processing line and results in fewer bypassed fields due to planting, mistiming, or weather delay (Marshall and Tracy, 2003). However, according to Warzecha (2003), it is easier to mechanise the harvest of standard sweet corn than that of shrunken sweet corn. The standard sweet corn compares to shrunken varieties mature to longer. Sweet corn has a very short period of optimum harvest maturity, and its quality changes rapidly close to and following the peak. Ears harvested immature will have a small diameter, a poor cob fill, and kernels that are watery and lack sweetness. At optimum harvest maturity, the kernels are plump, sweet, milky, tender, and nearly of maximum sizes. After optimum harvest maturity has been reached, the eating quality of sweet corn begins to decrease rapidly, while the husk appearance changes very little. Overmature corn is rather starchy than sweet, tough, and the kernels are often dented (Motes et al., 2007). However, according to Kumari et al. (2007), the unfavourable correlation coefficients between the sugar content and grain weight suggested that it is difficult to obtain high-yielding sweet corn hybrids of good quality.

Results of sweet corn ear size measured at different harvest date are presented in Table 2. 


\begin{tabular}{|c|c|c|c|c|c|}
\hline \multirow{2}{*}{ Particular } & \multicolumn{4}{|c|}{ Harvest date } & \multirow{2}{*}{$\begin{array}{c}\text { LSD } \\
\alpha=0.05\end{array}$} \\
\hline & $1 \mathrm{st}$ & 2nd & $3 \mathrm{rd}$ & 4th & \\
\hline Moisture content (\%) & $\begin{array}{l}77.41^{\mathrm{a}} \\
(0.95)\end{array}$ & $\begin{array}{l}75.62^{\text {ba }} \\
(0.88)\end{array}$ & $\begin{array}{l}72.31^{\mathrm{c}} \\
(1.05)\end{array}$ & $\begin{array}{l}69.83^{\mathrm{d}} \\
(1.09)\end{array}$ & 2.05 \\
\hline Yield $\left(\mathrm{t} \cdot \mathrm{ha}^{-1}\right)$ & $\begin{array}{l}18.64^{\mathrm{a}} \\
(1.15)\end{array}$ & $\begin{array}{c}17.98^{\text {ba }} \\
(1.21)\end{array}$ & $\begin{array}{l}16.31^{c} \\
(0.98)\end{array}$ & $\begin{array}{c}15.88^{\mathrm{dc}} \\
(1.11)\end{array}$ & 1.20 \\
\hline Length $(\mathrm{cm})$ & \multicolumn{4}{|c|}{$22.21(2.09)$} & - \\
\hline Max. diameter $(\mathrm{cm})$ & \multicolumn{4}{|c|}{$4.94(0.98)$} & - \\
\hline $\begin{array}{l}\text { Number of kernels per row } \\
\text { (pcs) }\end{array}$ & \multicolumn{4}{|c|}{$28.05(1.57)$} & - \\
\hline $\begin{array}{c}\text { Number of kernel rows } \\
\text { (pcs) }\end{array}$ & \multicolumn{4}{|c|}{$14.72(1.54)$} & - \\
\hline Bulk density $\left(\mathrm{kg} \cdot \mathrm{m}^{-3}\right)$ & $\begin{array}{c}612.21^{\mathrm{a}} \\
(9.12)\end{array}$ & $\begin{array}{c}619.54^{\mathrm{ba}} \\
(8.65)\end{array}$ & $\begin{array}{c}624.36^{\mathrm{cb}} \\
(10.21)\end{array}$ & $\begin{array}{c}634.54^{\mathrm{d}} \\
(8.86)\end{array}$ & 9.36 \\
\hline
\end{tabular}

Numbers in the same line followed by the same letter are not significantly different at $p<0.05$.

Table 2. The mean values of kernels moisture content, yield ears, ear length, ear diameter, number of kernels per row, number of kernel rows and bulk density with standard deviation in parenthesis

The mean size of 100 husked ears measured at a first harvest date are: length $22.21 \pm 2.09 \mathrm{~cm}$ and max. diameter $4.94 \pm 0.98 \mathrm{~cm}$. The yield decreased from 18.64 to $15.88 \mathrm{t} \mathrm{ha}^{-1}$, when the moisture content of kernels decreased from 77.41 to $69.83 \%$. The similar decreasing of moisture content with increasing harvest maturity has been reported by Wong, (1994).

At all harvest date (moisture contents), an increase of deformation with an increase in applied forces was observed (Table 3).

\begin{tabular}{|c|c|c|c|c|c|}
\hline \multirow{2}{*}{ Particular } & \multicolumn{4}{|c|}{ Harvest date } & \multirow{2}{*}{$\begin{array}{c}\text { LSD } \\
\alpha=0.05\end{array}$} \\
\hline & 1st & 2nd & $3 r d$ & 4th & \\
\hline Compression force $(\mathrm{N})$ & $\begin{array}{l}29.48^{a} \\
(1.78)\end{array}$ & $\begin{array}{c}35.54^{\text {ba }} \\
(1.32)\end{array}$ & $\begin{array}{l}42.71^{c} \\
(1.54)\end{array}$ & $\begin{array}{c}49.56 \mathrm{dc} \\
(1.23)\end{array}$ & 7.11 \\
\hline Shear force $(\mathrm{N})$ & $\begin{array}{l}8.21^{\mathrm{a}} \\
(0.28)\end{array}$ & $\begin{array}{c}10.41^{\mathrm{ab}} \\
(0.32)\end{array}$ & $\begin{array}{c}12.34^{\mathrm{cb}} \\
(0.41)\end{array}$ & $\begin{array}{c}15.21 \mathrm{dc} \\
(0.37)\end{array}$ & 3.21 \\
\hline Puncture force $(\mathrm{N})$ & $\begin{array}{l}9.11^{\mathrm{a}} \\
(0.18)\end{array}$ & $\begin{array}{c}12.65^{\text {ba }} \\
(0.19)\end{array}$ & $\begin{array}{c}15.28^{\mathrm{cb}} \\
(0.17)\end{array}$ & $\begin{array}{c}17.23 \mathrm{dc} \\
(0.21)\end{array}$ & 4.56 \\
\hline
\end{tabular}

Numbers in the same line followed by the same letter are not significantly different at $\mathrm{p}<0.05$.

Table 3. The means values of compression, shear and puncture force with standard deviation in parenthesis

The hull rupture is marked by an audible "click", and a sudden decrease of the force occurs. The point marked by the abrupt force decrease is often called the bio-yield point and the loading was stopped once this point was reached. The measured parameters were the rupture force, when the kernel hull undergoes failure during compression, shear and puncture, the deformation up to the rupture point. 
The force required for the hull rupture increase as the moisture content decreased. At the moisture content ranging from 77.41 to $69.83 \%$ the compression force increased from 29.48 to $49.56 \mathrm{~N}$, the shear force increased from 8.21 to $15.21 \mathrm{~N}$ and the penetration force increased from 9.11 to $17.23 \mathrm{~N}$. Burton (1982) reported that the average puncture tensile strength forces increased with later harvest date.

During the period when sweet corn ears are suitable for harvesting and kernel moisture decreases total of sugars decreased from 6.24 to $5.11 \%$ and starch increased from 14.49 to $22.19 \%$ (Table 4 ).

\begin{tabular}{|c|c|c|c|c|c|}
\hline \multirow{2}{*}{ Particular } & \multicolumn{4}{|c|}{ Harvest date } & \multirow{2}{*}{$\begin{array}{c}\text { LSD } \\
\alpha=0.05\end{array}$} \\
\hline & $1 \mathrm{st}$ & 2nd & 3rd & 4 th & \\
\hline Total sugars (\%) & $6.24^{\mathrm{a}}(0.24)$ & $\begin{array}{l}5.92^{\text {ba }} \\
(0.21)\end{array}$ & $\begin{array}{l}5.54^{\mathrm{c}} \\
(0.19)\end{array}$ & $\begin{array}{l}5.11^{\mathrm{d}} \\
(0.18)\end{array}$ & 0.41 \\
\hline Starch $(\%)$ & $14.49^{a}(0.22)$ & $\begin{array}{c}16.21^{\text {ba }} \\
(0.24)\end{array}$ & $\begin{array}{l}18.70^{c} \\
(0.21)\end{array}$ & $\begin{array}{r}22.19^{d} \\
(0.23)\end{array}$ & 2.24 \\
\hline
\end{tabular}

Numbers in the same line followed by the same letter are not significantly different at $\mathrm{p}<0.05$.

Table 4 . The means values of total sugars and starch level with standard deviation in parenthesis

It was observed that the harvest date affect total sugars and starch level. The mean values of total sugars and starch only between 1st and 2nd harvest date weren't significantly different. (Table 2). Similar trend have been reported by Suk and Sang (1999).

The processing recovery and corn cut yield increased (from 41.14 to $50.02 \%$, and 7.67 to 7.94 $\mathrm{t} \cdot \mathrm{ha}^{-1}$, respectively) for different harvest date (Table 5).

\begin{tabular}{|c|c|c|c|c|c|}
\hline \multirow{2}{*}{ Particular } & \multicolumn{4}{|c|}{ Harvest date } & \multirow{2}{*}{$\begin{array}{c}\text { LSD } \\
\end{array}$} \\
\cline { 2 - 5 } & 1st & 2nd & 3rd & 4th & $\alpha=0.05$ \\
\hline Processing recovery $(\%)$ & $\begin{array}{c}41.14^{\mathrm{a}} \\
(3.48)\end{array}$ & $\begin{array}{c}43.13^{\mathrm{ba}} \\
(3.98)\end{array}$ & $\begin{array}{c}48.25^{\mathrm{cb}} \\
(4.11)\end{array}$ & $\begin{array}{c}50.02^{\mathrm{dc}} \\
(4.02)\end{array}$ & \multirow{2}{*}{6.86} \\
\hline Corn cut yield $\left(\mathrm{t} \cdot \mathrm{ha}^{-1}\right)$ & $\begin{array}{c}7.67^{\mathrm{a}} \\
(0.13)\end{array}$ & $\begin{array}{c}7.75^{\mathrm{ba}} \\
(0.11)\end{array}$ & $\begin{array}{c}7.86^{\mathrm{cb}} \\
(0.10)\end{array}$ & $\begin{array}{c}7.94 \mathrm{dc} \\
(0.12)\end{array}$ & \multirow{2}{*}{0.13} \\
\hline Bulk density $\left(\mathrm{kg} \cdot \mathrm{m}^{-3}\right)$ & $\begin{array}{c}585.51^{\mathrm{a}} \\
(9.42)\end{array}$ & $\begin{array}{c}592.31^{\mathrm{ba}} \\
(9.12)\end{array}$ & $\begin{array}{c}601.74^{\mathrm{cb}} \\
(9.06)\end{array}$ & $\begin{array}{c}609.11^{\mathrm{dc}} \\
(9.21)\end{array}$ & \multirow{2}{*}{12.36} \\
\hline
\end{tabular}

Numbers in the same line followed by the same letter are not significantly different at $\mathrm{p}<0.05$.

Table 5. The means values of processing recovery, corn cut yield and bulk density with standard deviation in parenthesis

The explanation for these increase of recovery could be found in the decline of moisture level and increases of starch content. Michalsky (1986) found that lower average moisture content and higher starch level make easy to mechanical cutting the kernel off the cob and reduce losses of kernel flesh. This is why the sweet corn for whole kernel canning is harvest at lower moisture content than for frozen - style corn. Although corn cut yield was the highest at the lowest moisture content $(69.83 \%)$ it was observed that some single kernels begun to wrinkle. A similar result was reported by Olson (2000), who found that the 
highest quality cut corn from most of the standard sweet corn hybrids would be obtained at a kernel moisture level of 72 to $73 \%$. At 74 to $75 \%$ moisture, the flavor and taste were good but kernel size and uniformity, color, and cut-corn yield of the standard sweet hybrids might be below par. At 70 to $71 \%$, a critical dividing point, yield was higher but the cut corn would appear to be older (large; darker yellow kernels) and might be tougher.

\subsection{Kernels removing from the cobs}

\subsubsection{Cutting method for removal of kernels from raw sweet corn cobs}

The food processing industry currently applies machines utilizing rotary cutter heads for severing corn kernels (Kessler and Harry, 1998) (Fig. 2).

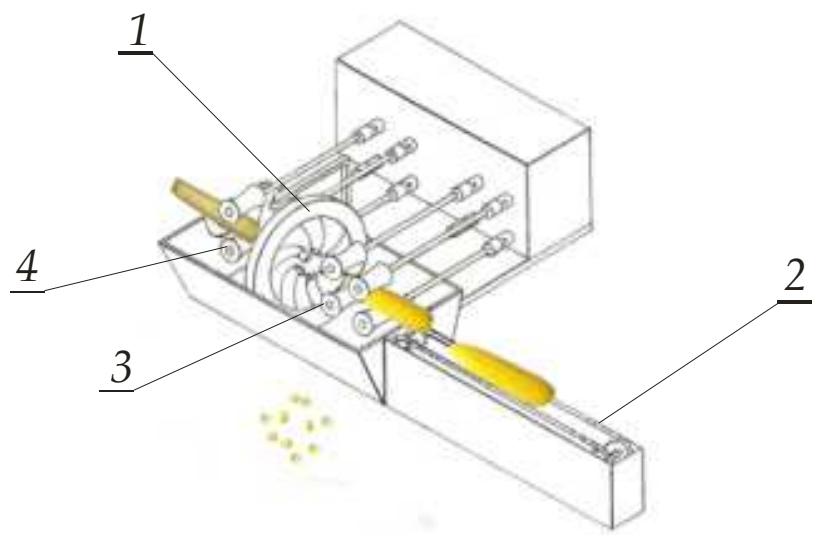

Fig. 2. Schematic of sweet corn kernel cutter: 1 - knife head, 2 - feeder of cobs, 3 -,rollers of copying system, 4 - removing rollers of cob cores (Robertson and Farkas, 1982).

The action of separating sweet corn kernels from the cob for consumption purposes is performed with the use of special cutters, the operation of which is described by many authors. To obtain kernels of high quality, the working elements of such machines should be carefully adjusted so that all the kernels are cut off as close to the cob core as possible, but without cutting off the cob husks whose presence among the kernels acquired worsens the quality of the product. Until recently it was recommended that kernels should be cut off at $2 / 3$ of their length with the kernel germs remaining on the cob core, as predominant in corn production were varieties with long cob husks. New hybrid varieties of corn are free of that defect, and to increase the amount of material acquired cutter knifes are set to the maximum length of kernels detached. Care must be taken that the cut through the kernel be smooth, without tearing the seed cover, and set so that no thick cob husks are among the kernels detached. This requires frequent sharpening of the cutter knives. Adjustment of the working elements of the kernel cutter should be made suitably to changes in the dimensions and properties of the material processed. Corn cobs should oriented with their narrower end towards the cutter head, as in that position the cutter knives adapt better to correct detachment of kernels. During kernel cutter operation, it is necessary to systematically check 
all the moving elements of the machine, and to clean and lubricate as required. This has an immense effect on the quality of kernels detached, as with the cutter head dirty the positions of cutter knives take longer to adjust to the changing cob diameter, and them may result in increased amount of incorrectly cut off kernels.

The mechanical removal of sweet corn kernels from the cob by cutting leads to waste, loss of nutritional value, and loss of yield (Hanna et al., 1988). This means that it is not possible to obtain all the kernels of corn. The cutting operation severs the upper part of the kernel from the lower part, which remains on the cob. Thus, the hull of the kernel is broken open and a part of each kernel is wasted (approximately 20\% remains on the cob), including much or the entire germ of the kernel. Furthermore, during subsequent wet-processing, including washing and blanching of the severed kernels, some of the corn meat is leached from its pouch and lost (Kunicki, 2003). However the proportion of cut-off kernels is strictly related to the moisture product processing characteristics. The successful detachment of sweet corn kernels as intact kernels promises large advantages in terms of yield and effluent over cut kernels during processing, but it does require low strength kernel attachment to the cob. The study by Niedziółka and Szymanek (2004) showed that blanching prior to the cutting process, instead of blanching after kernel cutting, resulted in a $12 \%$ increase in yield of cut kernels and quality. However, a similar study by Trongpanich et. al. (2002) did not show a statistically significant difference (0.05), while Michalsky (1986) reported that by delaying the time of harvest until the moisture content decreased, it is possible to increase the detached part of the kernel.

The studies of Szymanek (2011) showed that the cut kernel yield increased with the increase in cutter head angular speed. The change of speed from 167.5 to $293.2 \mathrm{rad} \cdot \mathrm{s}^{-1}$ increased approximately $51 \%$ for the Jubilee variety, $29 \%$ for the Boston variety, and 54\% for the Spirit variety. The differences recorded between the varieties were statistically significant. An increase of cutter head angular speed from $167.5 \mathrm{up}$ to $293.2 \mathrm{rad} \cdot \mathrm{s}^{-1}$ resulted in a statistically significant decrease of inferior kernel share. The highest reduction in inferior kernels in the investigated speed range was obtained for the Spirit variety, at about $64 \%$, whereas the lowest was for Boston, at about $44 \%$. An increase in the amount of kernels cut, along with a change of a cutter head angular speed, also decreased sugar content loss. The most substantial decline in sugar losses within the studied range of cutter head speed was observed for the Jubilee variety, with about $48 \%$, while the lowest for Spirit and Boston was about $33 \%$. A change in a cutter head angular speed generally resulted in a statistically significant effect on the differences in sugar content. Increasing cutter head angular speed in the range of 167.5 to $293.2 \mathrm{rad}^{\cdot} \mathrm{s}^{-1}$ induced a decrease in kernel mass losses subject to the plant variety. The changes were in the range from 51 to $28 \%$. Spirit variety had the highest reduction in sugar losses.

The losses occurring in the production process have negative effects not only in economical terms, but also pose considerable environmental pollution problems. The loss of kernels could, however, be reduced by means of the respective choice of sweet corn varieties. Robertson et al. (1980) think that solutions to this problem are being developed by food engineers and plant breeders by modifying the mechanical separation method and by modifying the raw product processing characteristics. However, claims that reduction of the 
kernel moisture could be achieved by delaying the cob harvesting dates, which, in turn, reduces loss during the kernel cutting process. In addition, blanching the cobs prior to attempting the cutting process (Stewart et al., 1997) and selecting the optimum operation parameters of the kernel cutter devices also reduces loss (Niedziółka and Szymanek, 2006). The method proposed by Robertson and Farkas (1982), whereby the cobs are halved along their length and the kernel is subsequently detached on reciprocally moving conveyor belts can practically reduce kernel loss to almost zero. However, this method is less efficient and consumes too much energy and has not so far been applied on industrial scale. In recent years, the growing concern about applying freezing methods, including cryo-liquids, in the food processing industry has also been reflected by the growth in manufacturing of frozen products, including sweet corn (frozen cobs or kernel). In highly technologically advanced countries, about $30 \%$ (20\% in Poland) of the production output of sweet corn is designated for freezing and about $40 \%$ for canned food (60\% in Poland) (Waligóra, 2006). Freezing in boiling liquids means very high convective heat-transfer coefficients, considerable temperatures and consequently very short freezing times. Unlike in classic (slow) freezing, the cryo-liquid freezing method results in a high quality of the product processed. Kernel frozen in temperatures of $-40 \mathrm{C}$ fit long-term storage requirements without any significant change in taste and technological properties (Matheus et al., 2004). The growing demand for frozen products brings about a need to develop technologies that can provide storage of fresh vegetables and fruit, while their physical properties undergo no essential changes.

\subsubsection{Shelling method for removal of kernels from frozen sweet corn cobs}

In the shelling method for removal of kernels from frozen sweet corn cob the corn cobs prior to shelling are subjecting to blanching and freezing by spraying in liquid nitrogen.

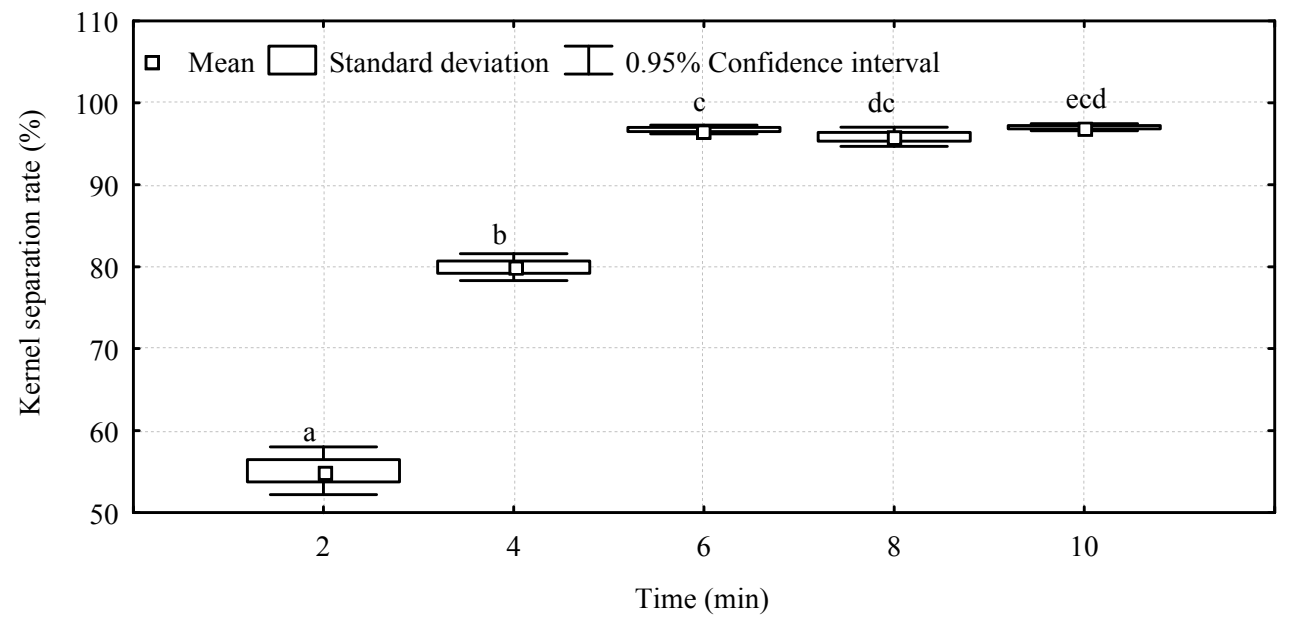

Numbers in the same letter are not significantly different at $\mathrm{p}<0.05$.

Fig. 3. The effect of freezing time on kernels separation rate 
The mean values of kernel separation rate of cobs for 2, 4, 6, 8 and 10 minutes freezing time were: $55.1 \% ; 79.9 \%, 96.7 \%, 95.8 \%$ and $97.0 \%$ respectively (Fig. 3 ).

In the range from 2 to 6 minutes freezing time we can observe the statistically significant increases of kernels separation rate and then from 6 to 10 minutes the not significant changes of kernels separation rate. This might be due to lack of uniformity in kernels freezing which results in different kernels hardness and not complete kernels removal.

The advantage of this method is the reduction of waste and increased yield of corn. During the analyses of kernels separation (Szymanek, 2011), it was confirmed that $86.3 \%$ of intact kernels removed after 2 and 4 min of freezing contained adhering cob related tissue, and $13.7 \%$ of kernels were without such tissue. However, for intact kernel freezing for 6,8 and $10 \mathrm{~min}$, the relations were opposite and amounted to, respectively, 8.9 and $91.1 \%$. This means that the optimal freezing time influences not only the quantity but also the quality.

Robertson et al. (1980), in a comparison between cut and intact kernels, found that intact kernels have more adhering cob-related tissues which is perceived as a defect of intact kernels

In the range from 2 to 10 minutes were observed the decrease of kernels damage from 7.3 to $3.9 \%$. The share of damaged kernels showed the same tendency as changes of kernels separate rate. The proportions of damaged kernels for 6, 8 and 10 minutes freezing time although different in value are not significantly different. Decreasing of kernels damages together with lengthen of freezing time might be due to increasing of hardness of whole kernels which results in kernels being more resistant to mechanical action of shelling unit. The mechanism of damages formation can be compared to threshing dried cob. Nguyen (1986) reported that when shelling dried cob, only the linkage between kernel and corn cob is broken When threshing fresh cob, we have to break down two linkages: kernel - corn cob and kernel - kernel. This causes a considerable amount of broken kernels. Similar situation might occur when freezing kernels.

\section{Summary}

The use value of sweet corn, resulting from its high nutritional values, taste qualities, and extensive possibilities of application, fully justifies the sense of increasing the area of its variation. The search for new and more efficient methods of harvest at simultaneous assurance of favorable economic effects and high quality requirements for the sweet corn cobs and kernel produced, become a necessity. Sweet corn cobs harvested for the processing industry are subjected to machining consisting in the kernel cutting off from cob core. Since a considerable part of sugars is cumulated in the lower part of the kernel, it is recommended to cut kernels off cobs as close to the core as possible. The irregular shape of kernels and their low content of dry mass (approx. 27\%) are the reason for frequent mechanical damage to kernels. Kernels, especially those located at extreme parts of the cob, differ in their size and hardness. Also the shapes of cobs (cylindrical or tapered) and their variable size (variety-related) make the detachment of kernels more difficult. Hence the process of kernel cutting off from cob cores is a major problem for the processing industry. 
The study has shown that sweet corn kernels can be removed from the cob by using shelling method when there are first subject to rapid freezing by spraying liquid nitrogen. The freezing time of 2, 4 and 6 minutes affects significantly the increase of hardness and separation rate and decrease of damage and kernels losses. Starting from 6 minutes freezing time, the time of 8 and 10 minutes had no significance effect on average values of analysed parameters. The visual observation of kernels showed that for freezing time of 2 and 4 minutes $86.3 \%$ of intact kernels had and $13.7 \%$ had not adhering tissue. In contrast, after 6,8 and 10 minutes freezing time only $8.9 \%$ of intact kernels had and about $91.1 \%$ had not adhering tissue.

\section{References}

Azanza, F.; Tadmor, Y.; Klein, B.P. (1996). QTL influencing chemical and sensory characteristics of eating quality in sweet corn. Genome, Vol. 39, 40-50.

Burton, L.V. (1982). The measurement of maturity of country gentlemen corn. Canner, Vol. $54,27-29$.

Collins, J.K.; Biles, C.L. (1996). Flavour qualities of frozen sweet corn are effected by genotype and blanching. J. Sci. Food and Agric., Vol. 72(4), 425-429.

Evensen, K.B.; Boyer, C.D. (1986). Carbohydrate and Sensory Quality of Fresh and Stored Sweet Corn. J. Amer. Soc. Hort.Sci., Vol. 111(5), 734-738.

Felczyński, K.; Bąkowski, J.; Michalik, H. (1999). Czynniki wpływające na jakość plonu i wartość odżywczą kukurydzy cukrowej. Ogrodnictwo, Vol. 3, 18-22.

Hanna, H.Y.; Story, R.N.; Adams, A.J. (1988). Effects of sweet corn production practices on yield and other characteristics. ASHS-SR Meeting, New Orleans, LA, Feb HortScience, Vol. 23(5), 824.

Hardenburg, R.E., Watada, A.E. (1986). The Commercial Storage of Fruits, Vegetables, and Florist and Nursery Stocks. U.S. Dept. Agric. Handbook, Vol. 66.

Ito, G.M.; Brewbaker, J.L. (1991). Genetic analysis of pericarp thickness in progenies of eight corn hybrids. J.Am.Soc.Hort.Sci.,Vol. 116(6), 1072-1077.

Kessler, Jr.; Harry, T. (1998). Machine for cutting krnels from ears of corn. USA Patent 5830060.

Kumari, J.; Gadag, R.N.; Jha G.K. (2007). Genetic analysis and correlation in sweet corn (Zea mays) for quality traits, field emergence and grain yield. Indian J.Agric. Sci., Vol. 77(9), 613-615.

Kunicki, E. (2003). Uprawa kukurydzy cukrowej. Kraków, Polska, Plantpress.

Lee, Y.C.; McCoon, M. (1981). Lipoxygenase and off -flavor development in some frozen foods. Korean J. Food Sci. Technol., Vol. 13, 53.

Marshall, S.W.; Tracy, W.F. (2003). Sweet corn. In: RAMSTAD P.E., WHITE P. (eds.): Corn Chemistry and Technology. American Association of Cereal Chemists, Minneapolis, 537-569.

Matheus, A.O.R.; Martinez, N.M.; Bertorelli, L.O. \& Venanzi, F. (2004). Adaptability of sweet corn ears to a frozen process. Archivos Latinoamericanos de Nutricion, Vol. 54(4), 43843.

Michalsky, F. (1986). Sweet corn - Vegetable of future? Mais, Vol. 2, 40-43. 
Motes, J.E.; Roberts, W.;Cartwright, B. (2007). HLA-6021-Sweet corn production. Available at http:/ / osufacts.okstate.edu.

Nguyen, Q.L. (1986). Sledonanie kvality praùce zberaca kukurice. Proceedings of the International Conference. Grain harvest, 161-163. Nitra-Czechoslovakia

Niedziółka, I.; Szymanek, M. (2004). Wpływ blanszowania na wybrane właściwości mechaniczne ziarna kukurydzy cukrowej. Acta Agrophysica, 4(2), 449-457.

Niedziółka, I.; Szymanek, M. (2006). Effects of some working parameters of corn cutter on cutting process. Inżynieria Rolnicza, Vol. 6, 81-89.

Olson K. (2000). Northland foods: planing the end. International Food and Agribusiness. Management Review, Vol. 3, 423-432.

Orłowski, M. (2000). Polowa uprawa warzyw. Kukurydza cukrowa, 383-386.

Puangnak, W. (1998). Effect of hybrid, maturity and kernel structure on lipid content, composition and aroma development in sweet corn, M.S. thesis, University of Maryland, College Park.

Reyes, F.G.; Varseveld, G.W. (1982). Sugar composition and flavor quality of high sugar (shrunken) and normal sweet corn. J. Food Sci., Vol. 47, 753-755.

Robertson, G.H.; Guadagni, D.G.; Lazar, M.E. (1980). Flavor and texture of preserved intact sweet corn: Comparison with cut sweet corn and storage tests. J. Food Sci. Vol. 45, 221-223.

Robertson, G.H.; Farkas, D.F. (1982). Apparatus for removing corn from cob. USA Patent 4318415.

Salunkhe, D.K.; Kadam, S.S. (1998). Handbook of vegetable science and technology; Production, composition, storage and processing. Marcel Dekker, Inc.

Scott, C.E.; Eldridge, A.L. (2005). Comparison of carotenoid content in fresh, frozen and canned corn. J. Food Comp. Anal., Vol. 18, 551-559.

Simonne, E.; Simonne, A.; Boozer, R. (1999). Yield, ear characteristics, and consumer acceptance of selected white sweet corn varieties in the southeastern United States. Hort. Technology, Vol. 9(2), 289-293.

Suk, S.L.; Sang, H.Y. (1999). Sugars, soluble solids and flavor of sweet, super sweet and waxy corns during grain filling. Korean J. Crop Sci., Vol. 44(3), 267-272.

Stewart, B.; Chevis, P.; Perera, C. (1997). Peroxidase isoforms of corn kernels and corn on the cob: Preparation and characteristics. Lebensmittel Wissenschaft und Technologie, Vol. 30, 192-201.

Szpaar, D.; Dregiew, D. (1999). Kukuruza. Uczebno-prakticzeskoje rukovodstvo po vyraszczyvaniu kukuruzy. Minsk.

Szymanek, M. (2011). Studies on shelling of frozen sweet corn. J.Food Proc. Eng., Vol. 34(3), 716-727.

Trongpanich, K.; Stonsoavapak, S.; Hengsawadi, D.; Lowitoon, N.A. (2002). A comparative study on pretreatment processes of canned whole kernel sweet corn. Kasetsart J.Nat. Sci., Vol. 36 (1), 63-68.

Wade, J.H. (1981). Characterization of aroma components of corn. Ph. D. thesis, University of Georgia, Athens.

Waligóra, H. (2006). Harvest and utilization of sweet corn. Kukurydza, Vol. 2(28), 26-27.

Warzecha, R. (2003). Słodki smak kukurydzy. Owoce warzywa kwiaty, Vol. 6, 20-21. 
Wong, A.D. (1994). A study of kernel composition affecting the quality of shrunken2 sweet corn. Disseration Abstracts International, 55(1) 10 Order no. DA9416451.

Wong, A.D.; Swiader, J.M. (1995). Nitrogen and sulfur fertilization influences aromatic flavor components in shrunken2 sweet corn kernels. J. Am. Soc. Hort. Sci., 120(5), 771-777. http:/ / attra.ncat.org/attra-pub/PDF/sweetcorn.pdf 


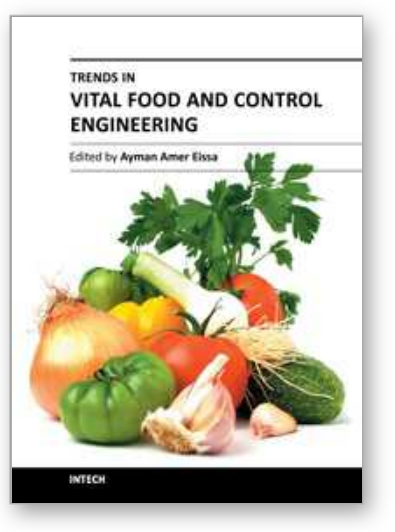

\author{
Trends in Vital Food and Control Engineering \\ Edited by Prof. Ayman Amer Eissa
}

ISBN 978-953-51-0449-0

Hard cover, 290 pages

Publisher InTech

Published online 05, April, 2012

Published in print edition April, 2012

This book is an example of a successful addition to the literature of bioengineering and processing control within the scientific world. The book is divided into twelve chapters covering: selected topics in food engineering, advances in food process engineering, food irradiation, food safety and quality, machine vision, control systems and economics processing. All chapters have been written by renowned professionals working in food engineering and related disciplines.

\title{
How to reference
}

In order to correctly reference this scholarly work, feel free to copy and paste the following:

Mariusz Szymanek (2012). Processing of Sweet Corn, Trends in Vital Food and Control Engineering, Prof. Ayman Amer Eissa (Ed.), ISBN: 978-953-51-0449-0, InTech, Available from: http://www.intechopen.com/books/trends-in-vital-food-and-control-engineering/processing-of-sweet-corn

\section{INTECH}

open science | open minds

\author{
InTech Europe \\ University Campus STeP Ri \\ Slavka Krautzeka 83/A \\ 51000 Rijeka, Croatia \\ Phone: +385 (51) 770447 \\ Fax: +385 (51) 686166 \\ www.intechopen.com
}

\author{
InTech China \\ Unit 405, Office Block, Hotel Equatorial Shanghai \\ No.65, Yan An Road (West), Shanghai, 200040, China \\ 中国上海市延安西路65号上海国际贵都大饭店办公楼 405 单元 \\ Phone: +86-21-62489820 \\ Fax: +86-21-62489821
}


(C) 2012 The Author(s). Licensee IntechOpen. This is an open access article distributed under the terms of the Creative Commons Attribution 3.0 License, which permits unrestricted use, distribution, and reproduction in any medium, provided the original work is properly cited. 